\title{
Magnetic particles in the sediments of the south Ukraine rivers as the marker of the technogenic impact on the hydroecosystems
}

\author{
Tetiana Alokhina
}

Section of geology and environmental problems of ore deposits, State Scientific Institution "Center for Problems of Marine Geology, Geoecology and Sedimentary Ore Formation National Academy of Sciences of Ukraine”, 50000, Kryvyi Rih, Ukraine

\begin{abstract}
Long-term and large-scale man-made activity in the mining areas affects to all components of the biosphere. The result of mining impact on hydroecosystems is addition to natural sources of sedimentary material technogenic components in large volumes. Magnetic particles are one of technogenic components which come with surface run-off to the river bed. We have studied the content of magnetic particles in the sediments of the south Ukraine rivers: the Inhulets River and the Inhul River - the tributaries of the Dnieper and the Southern Buh, respectively. The Inhulets River flows along the Kryvyi Rih iron ore deposit, parallel the river there is a chain of open-pits, mines, mining and processing plants, a metallurgical plant. The results of our research were demonstrated within the Kryvyi Rih industrial agglomeration a number of magnetic particles in the sediment samples varies from $59,5 \%$ to $2,1 \%$. Upstream from the Kryvyi Rih city on 10-15 $\mathrm{km}$ a number of magnetic particles is within $1,5 \%$. Based on numerous sources of literature and own researches, it has been determined that detection of magnetic particles and properties is a convenient, cheap, quick and informative method of technogenic pollution studying of river sediments and also mirror the industrial history of the region.
\end{abstract}

\section{Introduction}

River`s sediments, which are an element of the upper part of the section of the lithosphere and the lower part of the hydrosphere, carry information about the structure, composition, conditions of river valleys formation and catchment area.

In the significant anthropogenic impact areas, such as industrial territories and, especially, mining centres, to natural sources of sedimentary material in large volumes are added man-made components which come with wastewater, surface run-off, by direct movement stored material to the river bed. The technogenic components include in the general cycles of migration and sedimentation of deposition. The alluvial depositions in the man-made impact areas and downstream are a complex of particles of natural and unnatural origin $[1,2]$.

The bottom sediments of reservoirs and watercourses fulfill the depository mission of substances entering water from catchment areas, by erosion of shores and flush from adjacent areas. Thus, the composition of the bottom sediments reflects the ecological state of catchment areas and allows to reproduce the technogenesis process of the environment.

The most common types of man-made components of sediment are fragments of building materials, slag particles, synthetic materials (polymers, glass, rubber), coal, metal particles and spherules. The latter play a special role among the particles of anthropogenic origin, as they are the most common artificial component of bottom sediments $[2,3]$. In addition, this type of manmade bottom sediment material is not only easily identified due to its magnetic properties, but also allows to zone and stratifies sediments in the rivers and water reservoirs $[4,5,6,7]$.

The sources of man-made magnetic particles are mainly enterprises of metallurgical, coke-chemical production, metalworking. In addition, they are components of the ash of thermal power plants that use solid fuels (coal, peat), can be formed during welding and other technological processes.

The chemical composition of magnetic spherules has differences depending on the type of production, the product of which they are, and their subsequent transformation in hydroecosystems. In particular, a certain proportion of toxic chemical elements $(\mathrm{Pb}, \mathrm{Mn}$, $\mathrm{Zn}, \mathrm{Sb}, \mathrm{As}, \mathrm{Cd}$ ) can turn into an ionic form, thus polluting natural waters $[8,9,10,11,12]$.

\section{Literature review}

Finding of anthropogenic impact intensity, spatial zoning and monitoring of the pollution level, using the determination of the content of magnetic particles and the magnetic properties of bottom sediments is becoming a widely utilized method of environmental research.

China's rapid development of industry is in the last decades is attracting more attention in terms of pollution major rivers and coastal areas hydro ecosystems. China provides a huge mass of terrigenous sediments to the

Corresponding author: Alohkina@gmail.com 
marginal seas of East Asia and the north-western Pacific, which makes a significant impact on the marine sedimentation, primary production and, in general, biogeochemical cycles $[8,12,13,14,15]$. A number of studies to determine and compare magnetic properties in different sedimentogenesis environments [13] covered the Changjiang (Yangtze) and Huanghe (Yellow) Rivers, the topsoil of Loess Plateaus, Taklimakan desert sand and dust storms. It was found that the sediment of the Yangtze River is characterized by the highest content of magnetic minerals, the sediment of the Yellow River contains its much less, while the desert sand has the lowest concentrations of magnetic particles and large grain size. Magnetic properties of the Yangtze River sediment are primarily due to the diversity of lithology in its vast catchment area, while the gradual increase in the magnetic parameters of the Yellow River sediment are due to the size of the grains, which decrease on the way downstream.

A spot study at the mouth of the Yangtze River [8] determined the content of magnetic particles and the geochemical composition of subaquatic sediments and their changes over more than 50 years. The $236 \mathrm{~cm}$ long core, dated to a $\mathrm{Cs}^{137}$ activity level in the range of $140 \mathrm{~cm}$ and above, determined an average deposition rate of 3,11 $\mathrm{cm} \mathrm{yr}^{-1}$. The content of heavy metals and particles with magnetic properties increased with rising along the samples' core, demonstrating enrichment in the upper layers of the sediment. Geochemical and granulometric analyses have shown that source and size of the sediment do not play a very important role in magnetic properties changing. Diagenesis, which can lead to selective removal of magnetic components, was noted in the lower part of the core $(140-236 \mathrm{~cm})$.

The continental shelf of the East China Sea near the mouth of the Yangtze River is a complex sedimentary system characterized by specific hydrodynamic conditions and significant variability in sediment texture. Granulometric, geochemical and ecological magnetic properties of the surface layer of sediments were studied [15] to determine the spatial variations in the composition of deposits. Four zones were identified as a result of the research: the inner part of the mouth of the Yangtze River, the area with relic sands, the transition zone and the northern zone. The inner zone of subaquatic sediments is characterized by the highest content of ferromagnetic particles and the highest degree of their roundness, which corresponds to the sorting of sediments during their transportation by river. Strong magnetic properties of sediment in the northern zone are most likely due to the strong impact of the Yellow River. The obtained results make it possible to assess the degree of Yangtze impact on the composition and characteristics of the precipitation of the East China Sea shelf and lay the foundation for long-term monitoring of this important peripheral region.

The history of air pollution in a large industrial region of China has been successfully reconstructed based on studies of magnetic and chemical parameters of bottom sediments of reservoirs located in the area of Linfeng (China, Shanxi Province). For this purpose, the cores of bottom sediment were analysed, which were compared with the available data on air pollution. The regression equation between the magnetic properties of sediment, their chemical parameters and atmospheric monitoring data made it possible to reconstruct the history of air pollution in this region as fully as possible [14].

Studies of the magnetic properties and hydrocarbon content of the cores extracted from the north-east coast of Tamil Nadu (Bay of Bengal, India) found at depths more than 35 and $50 \mathrm{~cm}$ (depending on the core) a statistically significant increase in the content of magnetic particles. It indicates an excess anthropogenic load in the recent past. The gradual increase in the content of magnetic particles in the upper parts of the sedimentary cores is the result of the presence of ferromagnetic minerals of man-made origin. This study shows that instead of high-cost chemical methods the determination of magnetic properties is a convenient, cheap, fast and informative method of studying man-made pollution of marine sediments $[16,17]$.

Magnetic properties of the sediments of the Mandovi estuary (western India) were studied from 7 cores. The maximum values of the studied indicators were registered in the upper-middle part of the estuary and were 6 times higher than in the lower part of the estuary. Mineralogical studies have determined dominance of hematite and goethite in the upper-middle part of the mouth, while magnetite predominates in the lower part. The enrichment coefficient and index of metal accumulation indicated significant contamination of $\mathrm{Fe}$ and $\mathrm{Mn}$ in the sediments [18].

In the bottom sediments samples, taken on the Malay Peninsula, Sumatra, Borneo, Luzon and Taiwan, magnetic properties were studied: low-field magnetic susceptibility, anhysteretic (ARM) and isothermal (IRM) remanent magnetizations acquisition and decay, backfield acquisition, etc., as well as mineralogical analysis. The magnetic fraction of the sediment is a mixture of hematite, magnetite and pyrrhotite in different proportions depending on the region. It is noted that at present the magnetic fraction of the main river sediments, coming with terrigenous run-off to the South China Sea, is quite fully characterized and can be used as an indicator of man-made pollution [19].

Based on a large number of samples (216) of modern sediments, changes of magnetic properties of 6 clearly dated cores (by $\mathrm{Cs}^{137}$ ) taken from the central and northern parts of the Taiwan Strait were analysed. Differences in the lithology of Taiwan (predominance of pyrrhotite and magnetite) and south-eastern China lead to the formation of different mineralogical sediments obtained from the two banks of the Taiwan Strait. It has been estimated that terrigenous sediment from Taiwan has increased significantly over the past 5 decades, which is clearly correlated with extensive land use [20].

The samples of bottom sediments from 25 floodplains of 7 rivers in eastern Bohemia and 3 rivers in the northwest of England were taken to analyse hypothesis of enhanced magnetic properties in modern sediments of predominantly anthropogenic origin, as well as their applicability to long-term environmental change. Magnetic spherules in bottom sediments, which are most often formed by the combustion of fossil fuels, were recorded by scanning electron microscopy. For assess possibility to use of magnetic properties of sediments as a 
chronometer, they were compared with other used dating methods: the concentration of heavy metals and $\mathrm{Cs}^{137}$. The studied floodplain profiles were divided into 3 groups: the first group, which received the largest number of profiles, most fully reflected the production history of the regions and correlated with other dating methods. The second group received profiles that did not give a clear picture in terms of depth or parameters. All profiles from England were included in the third group because their magnetic properties were impacted by natural sources of magnetic particles, as well as the longer industrial history of the region. In general, it was determined that magnetic parameters are effective and reliable criteria for assessing river sediments [7, 21, 22].

Ecological study of the Siena River and its tributaries (France), with determining the magnetic parameters of alluvial deposits, was carried out to trace geological and anthropogenic processes and identify traces of denudation, regional distribution of suspended particles in comparison with anthropogenic impact. The chemical classification of each type of magnetic particles was carried out and the main tendencies of their accumulation, local features of the contribution of individual tributaries of the Siena to the total terrigenous run-off were determined. The applied interdisciplinary approach allows better understanding of hydrological and sedimentation processes in the large river systems, which in turn is crucial for our understanding of the relationship between geology, hydrology and ecology of river systems $[5,10,23]$.

Determining the degree of anthropogenic impact on hydro- and geosystems using indicators of the content of magnetic particles, spherules and their properties is now considered a reliable method of environmental research to monitor pollution and their spatial zoning.

A special place among the territories in which the bottom sediments are significantly "enriched" by magnetic components are the mining regions. It should be noted that the natural strong magnetic properties are inherent in minerals that contain iron. Among the latter are minerals that have strong magnetic properties (magnetite, titanomagnetite) and weakly magnetic properties (hematite, limonite, siderite, pyrrhotite, etc.); most iron silicates do not have pronounced magnetic properties. Under natural conditions iron minerals can enter the hydroecosystems from the weathering crust, where weak and non-magnetic minerals predominate. A significant increase of the minerals with strong magnetic properties from the horizons below the weathering crust or their constant entry into the hydroecosystems indicates their man-made origin, as they can get into the river system only due to technological processes of mining and iron ore beneficiation $[3,10,11,24]$.

Iron ore is mined in almost 50 countries. The largest production is in 10 countries, including China, Australia, Brazil, the Russian Federation, India, Ukraine and others. During 2018-2019 Ukraine held 7th place in the ranking of iron ore producers; during 2018 and 2019 years 62,5 and 60,0 million tons of iron ore were mined, respectively [25].

The specificity of Ukraine is the sharp dominance of waste generated during the development of mineral deposits (up to $75 \%$ of the total) and beneficiation (13$14 \%)[1,26]$. Man-made geochemical anomalies have formed on the Earth's surface in dumps and sludge storages, consisting of wastes from the enrichment of natural mineral or substandard raw materials, rocks of the upper part of the Earth's crust, which are not yet used in the economy. Crushed rocks, which were extracted and located on the surface, are subject to hypergenic changes under the impact of various natural factors. Man-caused geochemical anomalies created in this way are characterized increased, compared to background, concentrations of chemical elements, including dangerous pollutants $[1,11]$. The estimation only iron ore production makes it possible to understand why the area on the Earth's surface and on the sea shelf, where landfills, sludge dumps, tailings dumps, dumps and other manmade formations are located, is growing so rapidly. In the 1960 -s, their area was 4,5 million $\mathrm{km}^{2}$ (about $3 \%$ of the land), and in 2000, according to the US Bureau, it already exceeded 6,0 million $\mathrm{km}^{2}$ (about $4 \%$ of the land) [27].

\subsection{The aim of the research}

Kryvyi Rih iron ore basin, the largest centre of iron ore mining and processing in Ukraine, is one of the characteristic places of large-scale iron ore development. The territory, where $2,2-2,8$ billion tons of chemically pure iron have been extracted from a narrow meridional strip 1,0-3,0 km wide and 100-150 km long, has been mined during the last 125 years. Of course, long-term and large-scale technogenic activity in this region could not but affect all components of the biosphere: lithosphere, atmosphere, hydrosphere. In the composition of the sediment of rivers flowing through this area there are constantly products of man-made origin: magnetic spherules of metallurgical origin, particles of metallurgical slag, sludge, tailings and other waste.

The aim of our work was to research the content of magnetic particles in the sediments of southern Ukraine rivers and to determine man-made impact on hydroecosystems by this marker.

\section{Objects and method}

Studies of the bottom sediments of the Inhulets and the Inhul rivers, which are tributaries of the Dnieper and the Southern Buh, respectively, were carried out. Spot surveys of downstream of the Dnieper and the Southern Buh were also carried out. The choice of the study area is due to the significant anthropogenic pressure on hydroecosystems associated with the location of large industrial and agricultural facilities in this region.

The Inhulets and the Inhul rivers were surveyed from upstream to the mouth and 60 samples were taken from the Inhulets and 53 from the Inhul. The Dnieper River was explored lower the location of the Kakhovka hydroelectric power plant; the Southern Buh River was explored $143 \mathrm{~km}$ upper the confluence with the DnieperBuh estuary (figure 1). The total of 156 samples of bottom sediments were analysed. The thickness of the sediment layer taken for analysis was $0,1-0,35 \mathrm{~m}$. The selected 
samples after drying were averaged over the sampling points.

Determination of magnetic particles in sediments was carried out by the method [11,24] which is based on the finding of the total content of magnetic components of sediment (both natural and man-made origin). Significant increase of the components content with strong magnetic properties is observed in the man-made opening of rock horizons located below the weathering crust, as well as due to metallurgical processing of iron ore. Accordingly, the increased flow of the magnetic minerals to the hydroecosystems indicates their man-made origin. The latter can get into the river systems due to technological processes of extraction and iron ore beneficiation. The presence of a magnetic component in the bottom sediments, in quantities exceeding the average value for this type of sediment, can be considered a characteristic criterion of man-made transformation of hydroecosystems, especially mining regions [28].

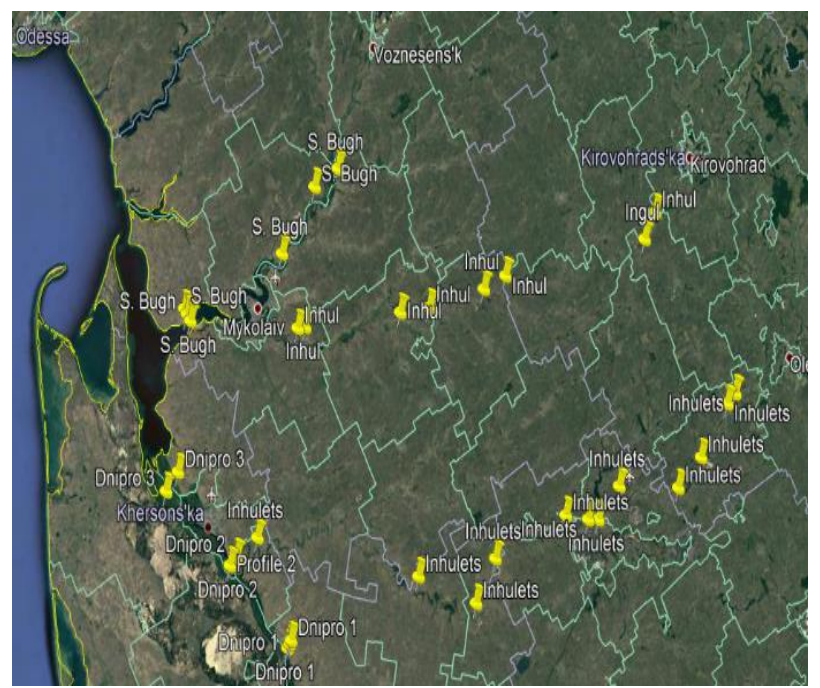

Fig. 1. Study area and sampling locations

The method of magnetic particles determining in sediments consisted of several consecutive stages:

1. Selected samples of sediments need to dry at a constant temperature of $105^{\circ} \mathrm{C}$.

2. The samples grind up and sieve through a $1 \mathrm{~mm}$ sieve. Five samples weighing $100 \mathrm{~g}$ take from the prepared material.

3. The prepared samples need to treat with a laboratory magnet $(0,2 \mathrm{~T})$. Then the separated magnetic fraction weighs and converts as a percentage per $100 \mathrm{~g}$ of dry sample.

Operations 1 - 3 are repeated for at least five specimen taken from each sediment sample, the results are calculated.

Due to the fact that sediments differ significantly in material composition (sand, clay, gravel, detritus, etc.) the error of the method was calculated depending on the source material. To do this, we used a number of mixtures consisting of a standard sample magnetic iron ore concentrate with an iron content of $70 \%$ and nonmagnetic sediment materials (sand, clay) in different ratios.
For mixtures of sand and magnetic iron ore concentrate the error is $0,2 \pm 0,02 \%$; for mixtures of clay materials and magnetic material $-0,4 \pm 0,06 \%$. The increase in the method error by study of clay sediments is due to magnetization and aggregation of fine clay particles.

\section{Results and discussion}

The Inhulets River flows along the great Kryvyi Rih iron ore deposit in the meridional direction. Parallel to the river there is a chain of open-pits, mines, mining and processing plants, a metallurgical plant. In the middle course of the river on the section 110-120 km long, the Inhulets flows within the mine allotment or not far from the mining enterprises, this distance is $22-25 \%$ of the total length of the river bed.

The results of the content and distribution studies of magnetic particles in the Inhulets River are shown in the form of a diagram (figure 2). The obtained data demonstrates that upstream 10-15 km the Kryvyi Rih city and its mining facilities the number of magnetic particles in the river's sediment is within 1,5\%. A similar situation is observed $25-30 \mathrm{~km}$ downstream of the Inhulets River from the city of Kryvyi Rih.

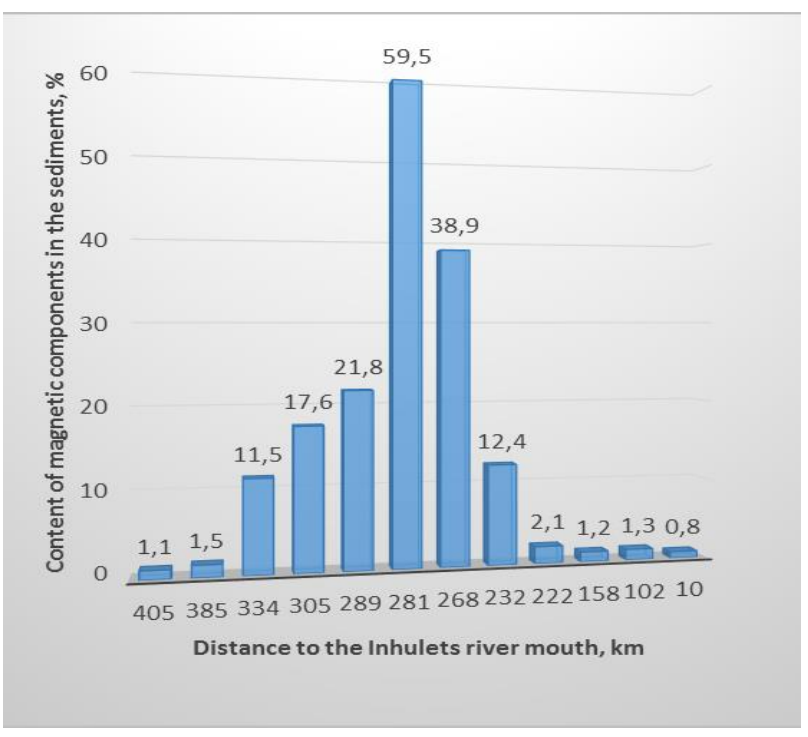

Fig. 2. The content and distribution of magnetic particles in the Inhulets River

Within the Kryvyi Rih city in the zone of intensive man-caused load, the number of magnetic particles in bottom sediment samples vary from $59,5 \%$ to $2,1 \%$. It can be argued with a high degree of probability; this anomaly is associated with the presence of iron ore beneficiation sludge in the bottom sediments. On the presented pictures (figure $3 \mathrm{a}, \mathrm{b}$ ) are shown that the river alluvium contains various magnetic particles of industrial origin. The maximum number of them is determined in the bottom sediment of the Inhulets River near the mining and processing plants and the metallurgical plant. As can be seen from the figure, the magnetic fraction consists mainly of iron ore beneficiation sludge. 
The Inhul River flows west of the Inhulets River at a distance about $100 \mathrm{~km}$. In the upper and middle stream the Inhul River crosses spurs and slopes of the Ukrainian Crystalline Shield. The territory, which the Inhul River through flows, is mostly used as agricultural land. The river section, of $190 \mathrm{~km}$ length in the middle course was studied by us, is subject to moderate anthropogenic impact. Studies of the magnetic particles presence in the Inhul River sediments have determined the content of this fraction as a little. The average content of the magnetic fraction is within $2 \%$. The magnetic particles distribution in the sediments of the Inhul River is the homogeneous throughout the studied section of the river. The presented results can be interpreted in the context of insignificant technogenic impact on the Inhul River, especially in its upper and middle part.

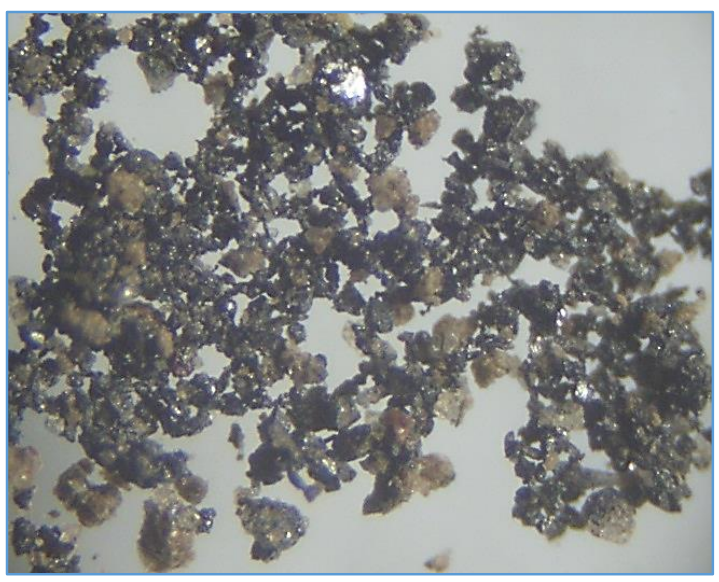

a)

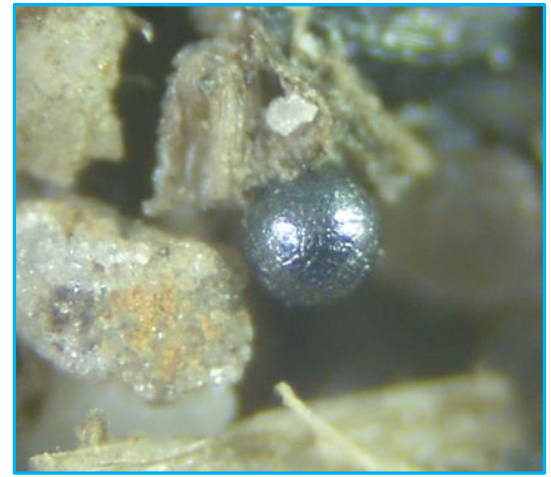

b)

Fig. 3. The iron ore beneficiation sludges, redeposited in the sediment of the Inhulets River (a), magnification 40x; a metallurgical magnetic spherule (b), magnification $250^{\mathrm{x}}$

The content of the magnetic component in the spot samples sediments taken in downstream of the Dnieper River ranged from $2,5 \%$ to $1 \%$. The moderate content of magnetic particles in downstream of the largest Ukrainian river can be explained by the Kakhovka Reservoir presence upstream. The latter retains $99,5 \%$ of all terrigenous materials to the Dnieper River, including man-made origin. Studies the magnetic particles determined in the sediments of the Southern Buh River indicate practical absence of the latter in the studied section of the river. The values, obtained by us, are $0,8-$ $1,5 \%$.
Comparing the studied rivers sediments in content of magnetic particles terms, we can assess the degree of man-made impact on hydroecosystems. Iron minerals are very common in the modern sediment of the Inhulets River. Studies have revealed the presence and steady growth of sources of iron-containing particles supply to river sediments these are dumps, tailings, mining sedimentation maps, as well as the territory of industrial enterprises.

Technogenic transformed particles of iron quartzite (crushed, beneficiated and displaced) are magnetic. Due to this, up to $59 \%$ of the sediments are among into the magnetic fraction in some parts of the river bed. Furthermore, sediments contain river-washed products of mining and metallurgical plants, which in addition to iron, contain wustite, magnetite, hematite, metallurgical glass. They are accompanied by metal graphite, sludge and slag particles, as well as copper, bronze, alloys of lead and tin, refractories and other industrial materials.

About 30 - $40 \mathrm{~km}$ downstream from the Kryvyi Rih iron ore basin the content of magnetic particles veraciously decreases, and at $\geq 50 \mathrm{~km}$ distance the technogenic components of the bottom sediment begin to acquire a "natural" rounded appearance.

Consequently, we can note that the result of largescale industrial and agricultural activity has radically changed sources and nature of terrigenous run-off in the catchment area of many rivers. The natural systems "weathering crust - river" partially, and in places completely, replaced by powerful systems of man-made materials transportation such as "dump - river", "sludge reservoir - river", "city - river". They changed the composition and properties of bottom river alluvium, and in some places and coastal shelf areas.

The technological method of production has led to the formation of a new type of bottom sediments - man-made, which differ significantly from natural. Widespread components of man-made sediments are metal particles and metal spherules, which are easily identifiable due to their magnetic properties. Identification of the anthropogenic component in modern sediments and ecological patterns of their distribution, to some extent, allow to outline their role in modern geological history. This lays the basis involvement of bottom sediments, as an integral component of monitoring of hydroecosystems, and determines the content and properties of the magnetic particles as a criterion for assessing the man-made impact.

\section{Conclusions}

Determining the degree of human impact on hydroecosystems with using of magnetic particles, spherules and their properties as indicators can consider a reliable method of environmental research to monitor pollution in space and their identification over time.

Long-term and large-scale man-made human activity in the Kryvyi Rih iron ore region has significantly affected on the hydroecosystem: in some parts of the Inhulets river bed more than $59 \%$ of the sediment is magnetic fraction. Determination of the content of magnetic particles in the sediments of the Inhul River, 
downstream of the Dnieper and the Southern Buh did not show high values. The latter is due to the predominance of agricultural activities in these areas.

On the basis of numerous sources of literature and own researches it has been determined that the detection of magnetic particles and properties is a convenient, cheap, quick and informative method of studying of technogenic pollution of river and marine sediments, and also mirror the industrial history of the region.

Magnetic particles in the river's sediments, which are losses of mining and processing plants, can be a valuable raw material. Valuable components that accumulate in the river sediment and carry to the shelf can be extracted along with dredging or cleaning works. This will allow integrated use of subaquatic sediments while restoring the natural state of water bodies. Search and research of localization of the greatest concentration places transformed components of geo-ecosystems, development of scientifically substantiated and ecologically safe technologies of their extraction and use as secondary raw materials can become a basis of the concept of balanced nature use.

\section{References}

1. I.M. Malakhov Novaya geologicheskaya sila (New geological force). (DC Ukraine, Kryvyi Rig, 2009)

2. E.A. Menschikova, Modern high technology 7, 183 (2010)

3. B.M. Osovetskiy, E.A. Menschikova Prirodnotekhnogennie osadki (Natural and technogenic sediment) (DC Permskyi university, Perm, 2006)

4. M.A. Chaparro, Environ. Geol. 45, 654 (2004)

5. J. Nizou, Comptes Rendus Geoscience 348 (6), 451 (2016)

6. D. Jordanova, Earth Planet Sci. Lett. 221, 71 (2004)

7. D.J. Robertson, K.G. Taylor, S.R. Hoon, Appl. Geochem. 18, 269 (2003)

8. D. Chenyin, Z. Weiguo, M. Honglei, Science of the Total Environment 476, 368 (2014)

9. F. Desenfant, E. Petrovsky, P. Rochette, Water Air Soil Pollut. 152, 297 (2004)

10. M.E. Evans Environmental Magnetism: Principles and Applications of Enviromagnetics. (Academic, Paris, 2003)

11. I.M. Malakhov, T.M. Alokhina, A.O. Bobko, Metodologichny pitannya transphormatsiyi geologichnogo seredovishcha $u$ hirnichovidoduvnikh regionakh (Methodological issues of transformation of geological environment in oremining regions). (DC Oktant Press, Kryvyi Rih, 2011)

12. T. Yang, L. Qingsheng, C. Lungsang, L. Zhendong, Environ. Geol. 52, 1639 (2007)

13. C. Li, S. Yang, W. Zhang, Journal of Asian Earth Sciences 45 (2), 190 (2012)

14. M. Ma, S. Hu, L. Cao, E. Appel, L. Wang, Environmental Pollution 204, 161 (2015)
15. S. Liu, W. Zhang, Q. He, D. Li, H. Liu, L. Yu, Geomorphologe 119 (3-4), 212(2010)

16. R. Venkatachalapathy, S. Veerasingam, N. Basavaiah, T. Ramkumar, K. Deenadayalan, Marine Pollution Bulletin 62 (4), 681 (2011)

17. R. Venkatachalapathy, S. Veerasingam, N. Basavaiah, T. Ramkumar, Marine and Petroleum Geology 27 (9), 1927 (2010)

18. Prajith, V. Rao, M. Pratima, M. Kessarkar, Marine Pollution Bulletin 99 (1-2), 338 (2015)

19. Cissel, Z. Liu, J. Li, C. Wandres, Sedimentary Geology 347, 10 (2017)

20. Horng, C. Huh, Earth and Planetary Science Letters 309 (1-2), 141 (2011)

21. M. Chudanicova, M. Simon, Catena 142, 21 (2016).

22. R. Thompson, Environmental Magnetism. (Allen and Unwin, London, 1986)

23. C. Franke, C. Kissel, E. Robin, P. Bonté, F. Lagroix, Geochem. Geophys. Geosyst. 10 (8) 234 (2009)

24. Alokhina T.M., Bobko A.O., Problems of bioindications and ecology 16 (2) 64 (2011)

25. Mineral Commodity Summaries 2019. (Geological Survey, Reston, U.S., 2019).

26. V.A. Kolosov Sostoyanie gornodobivayuschey promishlenosti Ukraini. Razrabotka rudnikh mestorozdeniy (The state of the mining industry of Ukraine. Development of ore deposits). (DC Oktant Press, Kryvyi Rih, 2004)

27. Mineral Commodity Summaries 2001. (DC Government Printing Office, Washington, 2001)

28. T.M. Alokhina, Problems of bioindications and ecology 22 (1), 110 (2017) 